\title{
ПЕРСПЕКТИВЫ СИСТЕМЫ ЦИФРОВОГО СЕЛЬСКОГО ХОЗЯЙСТВА В ПЛАНЕ ИНТЕГРАЦИИ В НЕЕ СИСТЕМЫ ПЛАНОВО-ПРЕДУПРЕДИТЕЛЬНОГО ТО И РЕМОНТА МАШИННО-ТРАКТОРНОГО ПАРКА
}

ТЮРИН Игорь Юрьевич, Саратовский государственный аграрный университет имени Н.И. Вавилова

ЛЕВЧЕНКО Галина Викторовна, Саратовский государственный аграрный университет имени Н.И. Вавилова

ЕРЮШЕВ Михаил Владимирович, Саратовский государственный аграрный университет имени Н.И. Вавилова

ШАРАШОВ Алексей Дмитриевич, Саратовский государственный аграрный университет имени Н.И. Вавилова

ШАРАШОВ Максим Дмитриевич, Саратовский государственный аграрный университет имени Н.И. Вавилова

В статъе рассматриваются перспективы системы цифрового сельского хозяйства в плане интеграции в нее обслуживания машинно-тракторного парка, что предполагает серъезное упорядочивание и экономию при четко прослеживаемом иифровом подходе. Сделан вывод о слабой проработке данных проектов на государственном уровне в РФ.

Введение. Сельское хозяйство - это достаточно сложная и трудоемкая отрасль, как в агропромышленном комплексе, так и во всем экономическом секторе. Это связано с воздействием на машинно-тракторный парк почвенно-климатических условий. Отрицательное их влияние, в определенной мере, связано с организационно-экономическими, технико-технологическими и непосредственно биологическими факторами $[9,10]$.

К сожалению, на данном этапе жизнедеятельности государства сельское хозяйство не является полноценно лидирующим видом производства.

Одним из важнейших принципов развития сельского хозяйства является его цифровизация, т.е. принцип ресурсосбережения, что предполагает использование энерго- и ресурсосберегающих программ и технологий.

Методика исследований. В своих исследованиях А.С. Бисалиев отмечает, что и сегодня по ряду областей сельское хозяйство России не вышло на уровни до 1990 года [3], что является следствием изношенности и несвоевременности действий в области планово-предупредительного технического обслуживания и ремонта (далее ППТОиР) машинно-тракторного парка (далее МТП) сельхозпредприятий.
Системыцентральных ремонтных мастерских хозяйств, ремонтно-обслуживающих заводов и предприятий, а также пунктов технического обслуживания России удовлетворяют потребности заказчиков не более $60 \%$ [2].

Вместе с тем, в парках сельхозпроизводств появляется все больше энергонасыщенной техники, что предполагает серьезное возрастание требований к качественному и своевременному ее ремонту.

Назначение ППТОиР МТП заключается в восстановлении у подержанной техники потребительских свойств, а именно: производительности, экономичности, надежности и т.П., которые были частично/полностью потеряны в связи с ее эксплуатацией. На вторичном рынке сельхозтехники услуги в области ППТОиР могут осуществляться как силами самого сельхозпредприятия, так и становиться базовым видом товара. Причем, от того, насколько организован данный сегмент, зависит эффективность его в качестве инструмента воспроизводства МТП [7].

Все же достаточно часто деятельность в области поддержания на требуемом уровне работоспособности и иных качеств МТП либо его восстановления требует привлечения соответствующих предприятий, занимающихся ремон- 
том на коммерческой основе. Соответственно, услуги в области ППТОиР - это товар, а значит, они создают соответствующие экономические отношения между покупателями-продавцами, кроме того, инфраструктурных участников данного рынка, к которым можно отнести рекламные, маркетинговые и иные агентства, финансово-кредитные организации и т.д. Все вышеизложенное предполагает серьезное упорядочивание и экономию при четко прослеживаемом цифровом подходе.

В перспективе, для повышения простоты и эффективности сельхозразвитие требует внедрения большого количества инновационных технологий, «от дронов до анализа данных и оптимизации ресурсов» [4].

Результаты исследований. Однако современные процессы цифровизации позволяют предложить возможность преодоления данного системного кризиса посредством интеграции вышеуказанной системы в общую систему цифрового сельского хозяйства. Данная мера дает возможность как позволить значительно сэкономить ресурсы, материальные и финансовые, так и оптимизировать данную часть затрат на производство сельхозпродукции в целом.

Следует отметить, что сегодня сущность цифрового сельского хозяйства можно определить как «совокупность связей и отношений между составляющими ее компонентами, частями, элементами, отличающуюся динамичностью и поступательным движением в пространственно-временном континууме» [3]. Таким образом, можно говорить о повышении результативности от применения цифровых систем в сельском хозяйстве, как комплекса мер целесообразных, обоснованных с экономической позиции, а также осуществимых технически.

Система цифрового сельского хозяйства, по мнению Н.Р. Амирова, способна создать более справедливую агропродовольственную цепочку создания ценности, поскольку цифровые технологии снижают операционные и транзакционные издержки, а также информационную асимметрию [1].

«Цифровизация» суть не одно лишь использование в производственной деятельности высокотехнологического программного обеспечения или оборудования, но также внедрение в процесс производства современных инструментов управления /бизнес-моделей [6].

Системы цифрового сельского хозяйства дадут возможность трансформации сельхозпредприятий на всех звеньях агропродовольственной цепи, на уровне каждого элемента. Оптимиза- ция, предсказуемость, а также разумность и индивидуальный подход как принципов цифровизации - залог этого [8].

В-целом, цифровизация сельского хозяйства, в первую очередь, предполагает информационное наполнение о процессах данной системы: от погодных условий до фиксации времени ППТОиР МТП по отношению к каждому его элементу, каждому механизму. Если же говорить об использовании робототехники, а также беспилотных летательных аппаратах, ЦСХ предполагает внедрение технологии искусственного интеллекта. Вместе с тем, инновации всегда являют собой возможность риска, что может быть одной из причин слабого внедрения цифровизации на данном уровне в РФ.

Кроме того, к данному процессу не следует относиться как к возможности частичного замещения, так как полноценную экономию и повышение эффективности сельхозпредприятия можно получить только лишь при использовании системной ЦСХ каждого конкретного предприятия с перспективой объединения фермеров в единую сеть с производителями необходимых для них товаров и покупателями, а также сопутствующими службами, в том числе, занимающимися ремонтом МТП.

Заключение. Следует отметить, что сельхозпредприятиям сегодня достаточно сложно полноценно перейти на принципы функционирования ЦСХ, так как, несмотря на отдельные подвижки властей на региональном и федеральном уровнях, у первых отсутствует как соответствующее финансирование, так и помощь в областях информационно-консультационной, правового обеспечения, общеуправленческой.

В предложенном ведомственном проекте «Цифровое сельское хозяйство» [5] возможность включения в цифровое сельское хозяйство структуры ППТОиР МТП не упоминается, что свидетельствует о слабой проработке данных проектов на государственном уровне.

Решение указанных проблем позволит цифровому сельскому хозяйству вернуть России возможность полноценного использования сельхозресурса.

\section{СПИСОК ЛИТЕРАТУРЫ}

1. Амирова Н.Ф., Саргина Л.В., Кондратьева Я.Э. Цифровые технологии в сфере сельского хозяйства // ЦИТИСЭ. - 2020. - № 2(20). - С. 266-280.

2. Ахметдинов Р.Ф. Техническое обслуживание и ремонт машинно-тракторного парка // Молодежь и наука. - 2018. - № 6. - С. 59.

3. Бисалиев А.С. Системный подход к цифровизации сельского хозяйства // Системный анализ и синтез моделей научного развития общества: 
сб. статей. - Уфа: ООО «Омега Саинс», 2020. С. $58-60$.

4. Болдарева Ю.О., Назарова А.В. Перспективы цифровизации сельского хозяйства России // Управление в экономических и социальных системах. 2020. - № 2(4). - С. 14-18.

5. Ведомственный проект «Цифровое сельское хозяйство»: официальное издание. - М: ФГБНУ «Росинформагротех», 2019. - 48 с.

6. Доброхотов К.О. Влияние цифровизации на устойчивое развитие сельских территорий // Наука и общество. - 2020. - № 2(37). - С. 50-52.

7. Кормаков Л.Ф, Казакова Г.Я. Ремонтно-технические услуги как форма товара и фактор воспроизводства машинно-транспортного парка // Экономика, труд, управление в сельском хозяйстве. - 2009. - № 1(1). - С. 14-18.

8. Норалиев Н.Х., Юсупова Ф.Э. Цифровые технологии в сельском хозяйстве // Вопросы науки и образования. - 2020. - № 8(92). - С. 4-10.

9. Тюрин И.Ю. Проблемы механизации процесса загрузки и выгрузки досушиваемого материала на воздухораспределительную установку при её эксплуатации // Образование, наука и производство. Научная компания «Наука и образование». - 2016. - № 1 (14). C. 34-35.
10. Тюрин И.Ю. Обоснование режимов работы воздухораспределительной установки // Научная мысль. - 2016. - № 5. - С. 86-89.

Тюрин Игорь Юрьевич, канд. техн. наук, доцент кафедры «Техническое обеспечение АПК», Саратовский государственный аграрный университет имени Н.И. Вавилова. Россия.

Левченко Галина Викторовна, канд. техн. наук, доцент кафедры «Математика, механика и инженерная графика», Саратовский государственный аграрный университет имени Н.И. Вавилова. Россия.

Ерюшев Михаил Владимирович, канд. техн. наук, доцент кафедры «Проектный менеджмент и внешнеэкономическая деятельность в АПК», Саратовский государственный аграрный университет имени Н.И. Вавилова. Россия.

Шарашов Алексей Дмитриевич, магистрант, Саратовский государственный аграрный университет имени Н.И. Вавилова. Россия.

Шарашов Максим Дмитриевич, студент, $\mathrm{Ca}$ ратовский государственный аграрный университет имени Н.И. Вавилова. Россия.

410060, г. Саратов, ул. Советская, 60.

Тел.: (8452) 74-96-63.

Ключевые слова: ицфровизация; сельское хозяйство; ремонт; техническое обслуживание; машиннотракторный парк; ведомственный проект.

\section{PROSPECTS OF DIGITAL AGRICULTURE IN TERMS OF INTEGRATION OF THE SYSTEM PLANNING-PREVENTIVE MAINTENANCE AND REPAIR OF THE MACHINE AND TRACTOR FLEET}

Tyurin Igor Yurievich, Candidate of Technical Sciences, Associate Professor of the chair "Technical Support of AIC", Saratov State Agrarian University named after N. I. Vavilov. Russia.

Levchenko Galina Viktorovna, Candidate of Technical Sciences, Associate Professor of the chair "Mathematics, Mechanics and Engineering Graphics”, Saratov State Agrarian University named after N. I. Vavilov. Russia.

Eryushev Mikhail Vladimirovich, Candidate of Technical Sciences, Associate Professor of the chair "Project Management and Foreign Economic Activity in Agro-industrial Complex", Saratov State Agrarian University named after N.I. Vavilov. Russia.
Sharashov Alexey Dmitrievich, Magistrandt, Saratov State Agrarian University named after N. I. Vavilov. Russia.

Sharashov Maxim Dmitrievich, Student, Saratov State Agrarian University named after N. I. Vavilov. Russia.

Keywords: digitalization; agriculture; repair; maintenance; machine and tractor fleet; departmental project.

The article discusses the prospects of the digital agriculture system in terms of integrating the maintenance of the machine and tractor fleet into it, which implies serious streamlining and savings with a clearly traceable digital approach. It is concluded that these projects are poorly developed at the state level in the Russian Federation. 